\title{
Fast Forward to the Past: A Look into Palestinian Collective Memory
}

Sonia Nimr

\section{(2) OpenEdition \\ 12 Journals}

Electronic version

URL: https://journals.openedition.org/clo/287

DOI: $10.4000 /$ clo. 287

ISSN: 2266-1816

Publisher

INALCO

\section{Printed version}

Date of publication: 1 January 2008

Number of pages: 338-349

ISBN: 978-2-85831-181-1

ISSN: 0396-891X

\section{Electronic reference}

Sonia Nimr, "Fast Forward to the Past: A Look into Palestinian Collective Memory", Cahiers de littérature orale [Online], 63-64 | 2008, Online since 01 January 2012, connection on 07 July 2021. URL: http:// journals.openedition.org/clo/287 ; DOl: https://doi.org/10.4000/clo.287

This text was automatically generated on 7 July 2021 .

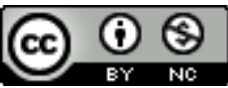

Cahiers de littérature orale est mis à disposition selon les termes de la Licence Creative Commons Attribution - Pas d'Utilisation Commerciale 4.0 International. 


\title{
Fast Forward to the Past: A Look into Palestinian Collective Memory
}

\author{
Sonia Nimr
}

1 I was young and wanted so much to join the revolt. But my father wouldn't allow me, and wouldn't give me the money to buy a rifle. My brother was already in the revolt, and my father needed someone to help him attend the land. But I insisted. Since he wouldn't give me money to buy a rifle, I went to the English police station and I stole a horse from there. I gave it to Rabah al Awad, who was one of the revolt leaders. I stayed with his group for two months but he didn't give me a rifle. So I stole the horse back from him and went to another leader. He gave me a rifle for the horse. Now it was up to me, and my courage. I stayed with his group until the end of the revolt. ${ }^{1}$

2 This may be one of the stories old people like to tell to whomever they find ready to listen. But it makes the listener live inside the event; it gives history other dimensions and a life which we rarely see in historical books. In the case of the Palestinian people, such stories gain an added special significance.

\section{Why Oral History?}

3 The complete destruction of Palestinian economic, social, political, and geographical structures after the establishment of the state of Israel created a stateless people. In the wake of the establishment of the state of Israel, some four hundred eighty Palestinian towns and villages were completely destroyed and around eight hundred thousand people (roughly seventy percent of the entire Palestinian population) became refugees.

Palestine, as its people and the world knew it, was divided into three separate parts: One came to be known as the West Bank, annexed by the Kingdom of Jordan; another, the Gaza strip, was administered by Egypt; and the biggest part (78\%) became the state of Israel.

5 The Israelis, thereafter, moved fast and effectively along three fronts: they destroyed and eliminated as much as possible the physical evidence and material signs of the 
previous existence of the Palestinian Arab people, their society, and their culture; they imported as many Jewish immigrants as possible in order to replace the Palestinians and populate the Jewish state; they prevented the return of Arab refugees across the border; and they changed the character of the country from an Arab to a Jewish land.

Set against this historical background, oral history and collective memory have become especially significant to the Palestinian people. During sixty years of exile from their homeland, their collective memory has helped them sustain and preserve their identity and culture, and it has given the younger generations in exile a sense of belonging to their homeland. It had been the backbone of the resistance against identity eradication. Collective memory is the only link to the past of a lost homeland. It is passed to the younger generations in as much detail as possible to protect the children from feeling alienated and insecure, and to insure that the younger generations receive at least part of their inheritance of a land in which they were not born. This homeland stays alive with the next generation, and to them passes the responsibility of its liberation.

I can describe my village in such details as if I have lived there all my life, I can tell you the color of the tree near the mosque, the smell of the flowers in my mother's garden, I can tell you the details of the battles as if I have been there myself. ${ }^{2}$

As a stateless people, the Palestinians compensated for the lack of official institutions, which document and preserve their history, by sustaining collective memories. In the refugee camps, the Palestinians re-grouped into a social structure which was as close as possible to their original, village society in Palestine. As far as conditions allowed, people from the same families and the same villages tried to stay in the same refugee camps in order to preserve and secure the continuity of village traditions and social structure. Thus, they were able to maintain many of their habits, costumes, customs, folk stories, sayings, songs, dance, and food. Most of all, they tried to maintain intervillage marriages in order to secure the continuity of village communities from one generation to the next (Weir, 1989; Sayigh, 1979).

It is important to note here, that while almost all forms of tradition and social institutions were preserved (as much as conditions in refugee camps allowed), folktales and traditional storytelling suffered a setback. In their intent to preserve the memory of their homeland and to ensure the continuity of that memory through the generations, people in the refugee camps replaced folktales with genealogical tales. The traditional storytelling of myths and legends was replaced by tales about the homeland, the ancestors, everyday life, the harvests, and even quarrels. "Clever Hasan", who saved the princess from the spell of a wicked witch, was replaced by the boy who took a gun to defend the village against the invaders. "The monstrous Ghoul' in the stories was replaced by another kind of monster, less mythical, but no less vicious, who occupied their land and ruined their lives. The exodus of "Abu Zaid al Hilali" to find peace was replaced by a forced exodus towards the unknown.

The same thing occurred with those Palestinians who remained in their villages under Israeli rule; collective traditional memory is a bulwark against the strangers who occupied their country and brought with them an alien culture. The Israelis regard the Palestinian Arabs in Israel as untrustworthy:

Peasants in general are passive people. They don't accept new things easily, especially if they are imposed on them. We kept our traditions, we took strong hold on them as a way of expressing our refusal of the new life and culture the Israeli occupation is imposing on us. ${ }^{3}$ 
11 Palestinian history has mainly been written by non Palestinians, according to the Churchillian dictum that victors write history. The international academy has tended to give greater credence to the works of foreigners including, notably, Israeli historians. In other colonies, long after their independence, the uphill struggle to write their own history by freeing their spirit of the effects of colonialism has begun. In the case of Palestinians, this process has been delayed by years of occupation and constant attempts to destroy their identity, culture and, consequently, our credibility.

\section{Working with One's own People}

\section{Change of Perceptions}

12 In this view, a number of Palestinian historians (including the writer of this article) began to pay special attention, in the past twenty years or so, to oral history, in their attempt to decolonize their own history on the one hand, and to preserve and pass it back to its makers on the other.

As a Palestinian working with my own people, I have been working in the field since the early nineteen eighties and I noted many observations about working with one's own people in a society with political turmoil and a rapidly changing political situation. In this paper, I will attempt to briefly outline some of these observations.

In general, Palestine is remembered as a paradise lost, especially when contrasted with the reality of exile or of living under occupation. Yet, the Palestinians do not attempt to obliterate from their memories the evils of certain times in the past, the poverty, the suffering under the British during the mandate period, the Zionist massacres of their kinfolks, or seeing their own villages being bulldozed. They don't attempt to paint the past with unreal colors.

[...] I tell you, we always talk about how nice it was in our villages, but we had to work hard, especially us women. I had to wake up at four in the morning and prepare breakfast, and then go to the land and work, until the afternoon, I prepared dinner and took care of the house, the children the garden and the animals. And what did my husband do? He went to the village guest house to have coffee and talk with the men. But still, as hard as it was, I was in my own home working in my own land not a wretched refugee camp void of dignity. ${ }^{4}$

Details about the homeland and about daily life are remembered vividly, with crystal clarity, to the last minute detail, and in a fairly constant way by the older generation. However, I found that the narration of the political events which took place in that homeland during sixty years of rapid political changes came out in a jumble of events, emotions, reactions, hopes and a constant effort to make sense out of all this.

During my research in the eighties and nineties, I have noticed that when the same people were interviewed again some years later (after more changes in the political arena), the events remained the same in their memory, but the way they re-narrated them came out differently.

The narrator often judges the past through his/her perception of the present. One narrator, interviewed in the nineteen eighties, was talking about the revolt against the British in 1936 and his role as a fighter in that revolt. At the end of the interview, he commented: 
What is the point? All that heroism and sacrifice, and we are still under occupation, if we had accepted the partition plan of 1947 we would have had a country of our own by now. ${ }^{5}$ nineteen nineties, they enthusiastically talked, in great detail, about what they did during the revolt. The women did not suddenly regain their lost memory; rather, they regained their self confidence. Between the first interview and the second, there was the Intifada (the uprising) in which women played a very important role for which they were often praised and appreciated. Because of this confidence and high esteem, they came to see their role in the previous revolt in a different light. More surprising, some women even shed their inhibition of talking about things deemed inappropriate in their conservative society.

I was going back home on the bus near Lajun, we were told that there was an English checkpoint. Search they said, there were ten or twelve English soldiers. They ordered the men to get off the bus. I was the only woman. One of the men was a little late, he came close to me and said: sister I am dead, they will surely hang me. I asked him what the matter was. He said he had a pistol. In those days they hang you if you have any peace of weapon. I said give it to me. And I hid it here (in my breast). An English soldier came up the bus, searched, and then they allowed the men back on the bus after thoroughly searching them. When the same man came near me, I handed him back the pistol, he whispered: how can I ever thank you, you had saved my life $[. . .]^{6}$

21 I found that women not only talked about their role in the revolt, but they also seemed more capable of defining that role and giving it importance. For example, when they talked (in the eighties) about what exactly they did, some said:

We just helped with food and water, helped the injured. We worked the land, and sometimes smuggled weapons.

Such statements, said in a matter-of-fact tone, made it seem as if they had done nothing out of the ordinary, as if they did these things every day. But in the nineties, they saw these very actions in a different light. For these women, such actions became acts of heroism. During three years (the duration of the revolt), women worked the 
land alone, an added burden to their already burdened life. Furthermore, smuggling weapons was not a daily routine; it was a dangerous and courageous act.

\section{Myth and Reality}

23 I found that people generally were able to distinguish myth from reality when it came to specific political events. However, they sometimes tended to mix them up, often without realizing that they were doing this most of the time. The events narrated were true, they did happen in reality, but the way they remembered them was so mixed up with imaginative details, or the event became hallowed in the narration. For example, in 1967, an Egyptian freedom fighter infiltrated inside the borders and was killed by Israeli soldiers near the village of Aboud. When the people of the village tell this story, he becomes a mythical figure coming out of fairytale or a mythology book:

He was so big it needed at least ten men to carry his giant body. We found him three days after he was martyred and he smelled of musk. From then on everyone who passes his grave smells musk, and everyone who goes there would be blessed all his life. If a flock of sheep passes near his grave they make more milk more than you can imagine.?

Yet, when the people of Aboud village talked about the 1967 war and what happened during this war, they were able to remember events with clarity, with no added details or any imaginative seasoning.

There is a desperate need for heroes or for some good news in a very bleak reality. It is not that people are not aware of these exaggerations or that these myths are untrue, rather the important point here is how people perceive the event: They create muchneeded legends based on ordinary people. During my research on the 1936-38 revolt against the British during the mandate period in Palestine, two men "Abu Jilda and al Arneet" were repeatedly mentioned to me as heroes of the revolt. Many stories about their legendary actions were told. But when I consulted references about these two men, I found that they were nothing but common thieves. What made them acquire the status of heroes was the fact that the British forces were never able to catch them. These two outlaws were transformed by the people into much talked-about heroes (and they thus acquired Robin Hood status), simply because the powerful police of the British Empire were not able to catch them.

Another, more recent example, can clarify this attitude. During the last Intifada of 2000, in the occupied West bank, a single Palestinian sniper managed to shoot thirteen Israeli occupying soldiers with an old, nineteenth-century rifle. Stories began spreading about this man. Some said he was an old rebel from the revolt of 1936 still hiding today (perhaps as a way to explain the very old rifle). As the story spread, they even began describing him (though none had seen him), so the description of this man became even more heroic. However, when he was caught years later, he turned out to be a twenty-year-old young man who had found the rifle buried in his backyard. But even after the truth has come out, people still preferred to repeat their own version of the story.

One can find similar stories in almost all villages, whereby they have created their own set of legends or heroes and added some imaginative details. This is what the oral historian sees happening to an experience on its way to becoming a memory, and a memory in the process of becoming history. 


\section{Personal / General} highest value at least with the first two generations of refugees. This is true because the Palestinians, especially those who ended up in refugee camps outside Palestine, have preserved the memory of their villages and towns and their way of life almost intact, and they transmitted this memory, in the same details, to the new generation born in exile.

Almost all interviewees shared one thing in common; that is, most did not separate the personal from the general. When asked about a certain political event, they talked about themselves in that event, where they were, what they were doing, how far or close the event was to their home, etc. For example, when I asked Bahja Mustafa (seventy years old) whether the English soldiers searched Palestinian women (during the British mandate), she gave me the following answer:

I was in Ibtin going back home. I had with me a bag of sweets which I bought to take

home, fish, and a sack full of mint leaves and vegetables $[. . .]^{8}$

I found that women tended to list more details while narrating an event, although they sometimes got sidetracked and ended up detailing something that was not connected directly to the story they were narrating. But, still later, I found that they managed to insert some specific, interesting, and colorful details. By comparison, men would start talking about themselves and cover the general through the personal; still, they were more general and less detailed than women. They were also very economical when it came to description. For example, men may describe a battle scene as follows:

[...] We were hiding in the bushes above the valley, when the soldiers came we started shooting at them [...]

Women, on the other hand, tended to give more details in their description:

[...] It was spring and mountains were green. We went to the mountain carrying bread and food for the men. I made "musakhan" 9 and carried it on my head, I was carrying my son who barley walked on my hip, my neighbor was carrying hot bread from the stove, and she tripped on a stone and almost dropped the bread [...]

Although my research was not specifically aimed at comparing women and men in their way of remembering events, I could not help but note these differences and arrive at two conclusions: First, men tended to talk about their own role while talking about an event, while women talked less about themselves and gave more importance to the event itself. Second, men tended to be more economical in detailed descriptions of the things surrounding the event, location or people, while women tended to remember small details, adding more color and soul to the event.

\section{Transmitted Memory}

Some historians believe that when memory is transmitted to the next generation, it loses some of its value; however, in the Palestinian case, transmitted memory has the Now, with the fourth Palestinian generation in exile, one researcher found that the memory was strong and vivid when it was transmitted from the first to the second generation. Yet, when the third and fourth generations retold the stories and renarrated events they had heard from parents and grandparents, their narrations became paler and less detailed (Amer, 2007). 

important has been the passing of time (sixty years), the passing away of the first generation, education, social and economic reasons, and the rapid and continuous changes in the political situation.

\section{Comparative Notes}

Although all the interviewees had the above characteristics in common, I noted some differences between them which I will outline briefly:

\section{Locations}

Although the interviewees had many things in common when telling their stories about certain events, I found some differences. First, the Palestinians who remained inside Israel and those in the refugee camps outside Palestine in Lebanon or Jordan, for example, tended to narrate fairly constant stories, as compared to those Palestinians living under occupation in the West Bank and Gaza Strip whose narrations varied. I believe that this is mainly because the latter have seen many political changes in their areas compared to a fairly stable situation in the other areas.

The people in refugee camps have more detailed memories about the past, as early as the thirties and forties, while the people who remained in their villages and towns (especially in the West Bank and Gaza) and were not subjected to exile, tended to remember less details. I think this can be explained as a kind of defense/survival mechanism against a difficult life as refugees in exile.

The people who remained in their own villages and towns inside Israel tended to be more conservative and held on more strongly to their intangible heritage, as compared with those who remained in their villages and towns in the West Bank and Gaza strip. There is a perfectly logical explanation for this. The people who remained in their own villages and towns in the West Bank and Gaza strip and who were not subjected to exile or to abandoning their home, did not feel that their identity was being threatened. Therefore, they did not feel the urgent need to defend it by preserving it intact. Thus, their intangible heritage was subject to natural developments: songs, dances, proverbs, even the traditional embroidered dress, have been changing and adapting easily in accordance with the evolution of the society. On the contrary, the Palestinians who remained in their villages inside Israel and the refugees in exile, found it necessary to keep their intangible heritage preserved intact in order to defend their identity which is constantly being threatened.

\section{Transmitted Memory}

It is not surprising that the transmitted memory to the third and fourth generations among the Palestinian refugees in the Diaspora is stronger and more vivid than that of their counterparts in the refugee camps inside Palestine (i.e. West Bank and Gaza Strip) for the same reasons explained above. 


\section{Gender}

Palestinian women, especially in refugee camps, were the treasurers and safe-keepers of the memory of the homeland. Even before the "catastrophe in 1948", the task of maintaining traditions and the intangible heritage was in their hands. They were the main safe-keepers of folktales, songs, proverbs, and social traditions. In exile, this role was intensified and they made it their responsibility to preserve and pass this heritage to the next generations. So it was quite natural, and not surprising at all, that during interviews, they came up with more details than the men. Even today, whether in the homeland or the Diaspora, women still maintain the same role and take on the responsibility of transmission to the next generation.

41 I can give an example from a personal experience. As I was growing up, my mother, who came from the town of Nablus, always uttered a proverb instead of giving me a straight answer to my questions. She had a proverb for every situation; my father, on the other hand, never voiced any proverbs. I can say the same thing about our female neighbors from whom I learned folktales and traditional songs. ${ }^{10}$

\section{Conclusion}

All these details and reflections in collecting oral data among Palestinian people show that the way events are remembered do not only change with time or subject matter, or with the time of interview, it is also affected by the current political situation and the way the narrator sees it. In other words, it is often the case that the narrator remembers the past with the eyes and the conscience of today. The gender and the geographical location of the narrator also affect memory. The event itself is often still imprinted in their memory, but the way they remember it is affected by the circumstances around them.

I believe that it is very important and necessary for oral historians and fieldworkers to conduct long-term research and re-record interviews over a long period of time in order to be able to capture changes in memory and witness history in the making.

In the end, the importance and uniqueness of oral history in the Palestinian case does not come from only narrating historical events, but from the way the narrator remembers these events and how. And if classical history is about the when and the what, oral history is about the how and the why. The uniqueness of Oral history comes from being about people themselves. It is the history of life.

\section{BIBLIOGRAPHY}

AMER, Tayser, 2007, Unpublished masters' dissertation, Birzeit University.

KANAANA, Sharif, 2000, Still on vacation!, SHAML, Ramallah, Palestine. 
SAYIGH, Rosemary, 1979, Palestinians from peasants to Revolutionaries, London, Zed Press.

WEIR, Shelagh, 1989, Palestinian Costume, London, British Museum publications.

\section{NOTES}

1. Abu Ali Baytam, Abu Snan village, Israel, interview 21.8.1985. The Revolt of 1936-39 against the British Mandate and the Zionist project.

2. A freedom fighter (refused to give a name), in the Shatilla refugee camp, Lebanon, 1980.

3. This was said by one interviewer from Galilee. In 1948 only 120,000 Palestinians remained in their own villages, to become Israeli citizens.

4. Muyassar Ali, Jenin refugee camp, 21.3.1990.

5. Mohammad Jaradat, Silat al Dhaher, Jenin, 4.2.1985.

6. Bahijah Mustafa, Yaabad, Jenin, 30.3.1985-22.8.1990

7. This story has been repeated by at least five people in Aboud village during my research there in the eighties.

8. Bahja Mustafa, Nazlat Sheikh Zaid, Jenin area, March, 1985.

9. Musakhan is a Palestinian traditional dish, made with chicken and bread covered with onions.

10. Presently a group of experts in intangible heritage are collecting folktales in different areas in Palestine. We found out that almost all of the folktales collected were told by women.

\section{ABSTRACTS}

During my research in the eighties and nineties I noticed that when the same people who were interviewed again, (though the events remain the same in their memory), the way they narrate them came differently. Many things interfere in shaping their narratives especially when related to political events of the past; the difficulty to separate the personal from the general. The narrator often judges the past through his/her view of the present. The changes in their perceptions of the events and themselves through the years, also changes the narration. There is often a mix up between myth and reality in the narration. The memory transmitted from generation to another. This played a very important role for the Palestinian people in Exile. The differences in the narration between Palestinians in Exile and those who remained in the homeland. The differences in the narrations between generations. The differences in the narration between women and men. All these factors have affected the changes in the narration, and the way narrators re-relay their stories.

Pendant mes recherches dans les années 1980 et 1990, j'ai remarqué que, lorsque des personnes étaient interrogées de nouveau, et bien que les événements fussent les mêmes dans leur souvenir, leur façon de les raconter était différente. De nombreux éléments interviennent dans la mise en forme de leur récit, particulièrement lorsque ceux-ci sont relatifs à des événements politiques passés ; la difficulté de séparer le personnel du général. Les narrateurs jugent souvent le passé à travers leur vision du présent. Les changements dans leur perception des faits et leur propre évolution à travers les ans modifient également le récit. On observe souvent un mélange entre mythe et réalité. La mémoire transmise d'une génération à l'autre. Cela a joué un rôle très 
important pour le peuple palestinien en exil. Les différences entre les récits des Palestiniens en exil et ceux qui sont restés sur place. Les différences entre les récits des différentes générations. Les différences entre les récits des femmes et des hommes. Tous ces facteurs ont influencé tant les changements dans la narration que la façon de re-raconter des narrateurs.

INDEX

Subjects: anthropologie (Asie)

Keywords: Exile, Gender, Memory Recall, Narrating Political Events, Palestine, Anthropology

Geographical index: Palestine

Mots-clés: exil, genre, narration d'événements politiques, remémoration 